\title{
LEGAL BASIS FOR THE FORMATION OF VOCATIONAL MEDICAL EDUCATION
}

\author{
Khayrullayev Chorikul Kazakovich \\ Associate Professor, PhD docent in Department of Medical Chemistry of Bukhara State Medical \\ Institute
}

\author{
Gulyamova Mavjuda Toshpo'latovna \\ Associate Professor, PhD docent in Department of Medical Chemistry of Bukhara State Medical \\ Institute
}

\author{
Shukurov Ilhom Boltayevich \\ Associate Professor, PhD docent in Department of Biological chemistry of Bukhara State Medical \\ Institute
}

Article DOI: https://doi.org/10.36713/epra6112

\begin{abstract}
ANNOTATION
The article examines the role of regulatory framework in the training of medical personnel. It also analyzes the activities aimed at ensuring the quality of medical education, increasing cooperation with foreign universities, raising the prestige of the university.
\end{abstract}

KEYWORDS. Health system, international education standard, medical care, quality of medical education

\section{INTRODUCTION}

Particular attention is paid to improving the social protection and health care system, improving the quality of medical services, training qualified medical personnel. The "Action Strategy" for the five priority areas of development of the Republic of Uzbekistan for 2017-2021 states that "... first and foremost, to further reform its primary link, the system of emergency and urgent care." (Decree of the President of the Republic of Uzbekistan.et al., 2017). Today the issue of providing the medical sector with modern-minded, well-educated, responsible and mature personnel is being addressed at the state level. The development of any industry depends primarily on the potential of personnel trained in this area.

\section{MAIN PART}

Although the most modern techniques, the latest technologies are introduced into the industry, the buildings are reconstructed and a perfect management system is formed, if there is a delay in staff training, the expected result in the development of the industry will not be. During the meetings with representatives of the health sector on January 5 and February 7, 2017, as well as in video conferences during 2017-2020, chaired by the President, the issue of training health workers, in particular, the study of international experience, the need to prepare proposals for further improvement of medical education. It is not in vain that it has been mentioned separately.

As part of the implementation of measures to reform the health care system in the country, 


\section{SJIF Impact Factor 2021: 7.13| ISI I.F.Value:1.241| Journal DOI: 10.36713/epra2016 \\ EPRA International Journal of Research and Development (IJRD)}

certain results have been achieved in the formation of a modern system of medical care, training of qualified medical personnel

First, the legal and regulatory framework for medical services and training of medical personnel has been improved;

Second, a number of practical measures have been taken to improve the quality of higher medical education quality management, update its content, improve the quality level, bring the system of higher education standards and quality indicators at all levels to a level comparable to world standards.

Third, a social and moral environment that supports democratic values in the management of medical education has been created, and corruption in the field has been curtailed.

Fourth, the legal basis for the establishment of a separate medical higher education institution for the training of highly educated personnel in the field of public health and sanitary-epidemiological control services has been created.

Today, the issue of providing the medical sector with modern-minded, well-educated, responsible and mature personnel is being addressed at the state level.

President of the Republic of Uzbekistan Shavkat Mirziyoyev at an enlarged meeting of the Cabinet of Ministers on the main results of socioeconomic development of the country in 2016 and the most important priorities of the economic program for 2017 "Critical analysis, strict discipline and personal responsibility (Mirziyoev SH.M. et al., 2017). in his report on the subject. He stressed the need to develop a set of measures aimed at creating an effective system for training and retraining of doctors and medical staff, both in our country and in leading foreign clinics. He also touched upon this issue in his meetings with health professionals. Over the past period, our state and government have made great strides in this area, changes in the system.

As a result of the reforms, the classification of medical education fields and specialties operating in the country is constantly being improved and meets modern requirements.

The list of fields of study of medical higher education institutions for bachelor's and master's specialties required in principle and independent inventory of higher education institutions themselves. The analysis and restructured internal structures put on the agenda to ensure the formation of this list in accordance with the material and technical base and scientific and pedagogical potential of each higher education institution. Due to the lack of specialized teachers (especially in the newly opened areas), substandard laboratory equipment and overwork of teachers (filling out paperwork), the quality of training in some areas has declined. Improving the list of specialties for each higher education institution and at the same time increasing the contingent in areas that are justified in society has been an important factor in improving the quality of education at no extra cost.

Free reform of the internal structure of higher education institutions, the fact that the reforms are not linked to the goals, the specificity of the profile and the lack of positive world experience in this area have significantly reduced the quality and efficiency of the educational process.

In accordance with the Decree of the President of the Republic of Uzbekistan dated May 5, 2017 "On admission to higher educational institutions of the Republic of Uzbekistan in the 2017-2018 academic year", from 2017-2018 academic year, targeted admission has been established. Now, according to the orders of the Council of Ministers of the Republic of Karakalpakstan, regional and Tashkent city government, admission to the bachelor's degree on the basis of a state grant will be carried out for regions with high demand for medical personnel.

At the initiative of President Islam Karimov, the Termiz branch of the Tashkent Medical Academy was opened on February 1, 2018. This day made a new change in the life of the oases, the dream of the people was realized. In cooperation with the Tashkent Medical Academy, online lectures on the basis of innovative technologies were organized for students to become highly qualified doctors. Wellknown professors and doctors of the Tashkent Medical Academy in the country teach students in various fields (Khayrullayev Ch.K. et al., 2020).

It should be noted that over the past period, special attention was paid to the training of masters in the system of training specialists on a two-stage basis. There are well-known problems with the training of masters, and simply put, the field has not been very successful. The main reason for this was the lack of acceptance, the lack of consumer demand for a narrow range of specialties, and the fragmentation of specialties into extremely small parts. In the context of the formation of the bachelor's degree, shortcomings and deficiencies in the training of masters have significantly reduced the status of national education. The participation of only 3-5 masters in each course of specialties does not encourage the full conduct of lectures and other classes.

The master's degree is, in fact, based on the teacher's individual work with the student, but the master's skills of independent work are not fully formed, and the teachers lack consistency and principles in individual work with the masters. It is no coincidence that during the meetings with representatives of the health sector, chaired by the President on January 5 and February 7, 2017, as well as in a video conference on March 30,2017, the issue 
of training medical personnel was highlighted. Although the most modern techniques, the latest technologies are introduced into the industry, the buildings are reconstructed and an excellent management system is formed, if there is a shortage of personnel, the expected result in the development of the industry will not be. As a result of reforms in the field of medicine, the ministry is now responsible for the retraining of health professionals, as well as the training of highly qualified scientific and pedagogical medical staff, the involvement of professors, bachelor's and master's students in research in modern areas of medicine.

In the field of medical education, the transition to a reduced education system in the field of medical work, improvement of teaching hours and targeted admission will cover the shortage of medical personnel by $15 \%$, targeted budget spending, as well as medical education in line with international standards.

In order to further improve the system of training highly qualified medical personnel for the Aral Sea region, increase the quality and scope of medical services provided to the population, ensure strong integration of medical practice with education and science, introduce advanced achievements and innovations in the treatment and diagnosis process. In accordance with the concept of development of the higher education system of the Republic of Uzbekistan until 2030, the Karakalpak Medical Institute was established by the Decree of the President of February 14, 2020 on the basis of the Nukus branch of the Tashkent Pediatric Medical Institute.

The training of highly educated personnel in the field of public health and sanitaryepidemiological services is being improved. Resolution of the President of the Republic of Uzbekistan ID-17215 "On improving the training of higher education in the field of public health and sanitary-epidemiological services" (Khayrullayev Ch.K., Khayrulayeva Z.Ch. et al., 2020). was submitted for discussion on April 28 and ended on May 13.

\section{CONCLUSION}

It should be noted that the training of highly qualified and competitive specialists for various socio-economic sectors of the Republic of Uzbekistan is the basis of the reform "University 3.0" envisaged in the Action Strategy and the Concept of Higher Education Development in five priority areas of development of the Republic of Uzbekistan in 2017-2021. To this end, a number of systematic measures are being taken to further improve the higher education system, develop research and innovation activities in the regions and expand international cooperation.

\section{USED LITERATURE}

1. Decree of the President of the Republic of Uzbekistan No. PF-4947. (February 7, 2017). "Strategy of actions for further development of the Republic of Uzbekistan for 2017-2021"

2. Decree of the President of the Republic of Uzbekistan. (December 7, 2018). "On comprehensive measures to radically improve the health care system of the Republic of Uzbekistan"

3. Resolution of the President of the Republic of Uzbekistan. (April 7, 2020). "On measures to introduce a completely new system of training and continuous professional development in the medical field"

4. Resolution of the President of the Republic of Uzbekistan No PP-4310. (May 6, 2019) "On measures to further develop the system of medical and pharmaceutical education and science"

5. Decree of the President of the Republic of Uzbekistan No. 5545. (September 25, 2018) "On the organization of the Fund "El-Yurt Umidi" under the Cabinet of Ministers of the Republic of Uzbekistan for training specialists abroad and communication with compatriots".

6. Resolution of the President of the Republic of Uzbekistan ID-17215. "On improving the training of higher education in the field of public health and sanitary-epidemiological services"

7. Mirziyoev SH.M. (2017). Critical analysis, strict discipline and personal responsibility should be the daily rule of every leader. Tashkent.

8. Khayrullayev Ch.K., Khayrulayeva Z.Ch. (august, 2020). "Family- institute for formation of spiritual and moral values". India, EPRA International journal of research and development, $p: 45-48$.

9. Khayrullayev Ch.K. (June, 2020). "The role of independent learning in the formation of personal competence". India, EPRA International journal of research and development. 